\title{
ХРОНИКА
}

DOI: $10.17805 /$ trudy.2016.5.10

\section{ХІ КОНКУРС НА СОИСКАНИЕ БУНИНСКОЙ ПРЕМИИ}

\author{
Н. В. Захаров \\ (Московский гуманитарный университет)
}

Аннотация: В статье подводятся итоги ХІ конкурса на соискание Бунинской премии по русской литературе, которая проводится ежегодно в Москве. В 2016 г. конкурс проводился в номинации «Художественная публициистика».

Ключевые слова: Бунинская премия; русская литература; Московский гуманитарный университет; художественная публицистика

\section{$11^{\text {TH }}$ AWARDING OF THE BUNIN PRIZE}

\author{
N.V. Zakharov \\ (Moscow University for the Humanities)
}

Abstract: This is a summary of the 11th annual awarding of the Bunin Prize in Russian literature. In 2016 the prize was awarded for outstanding contribution to opinion writing.

Keywords: Bunin Prize; Russian literature; Moscow University for the Humanities; opinion writing

25 октября 2016 г., в конференц-зале Московского гуманитарного университета состоялась церемония награждения лауреатов XI конкурса Бунинской премии. В торжественной обстановке подведены итоги конкурса, который в 2016 г. проводился в номинации «Художественная публицистика».

XI конкурс на соискание Бунинской премии, как и в прошлые годы, привлек большой интерес писателей, литературных журналов («День и ночь», «Дружба народов», «Литературная Вологда», «Наш современник», «Российский писатель», «Русскій Миръ», «Сибирские огни», «Сибирь», «Урал»), ведущих издательств («Академика», «АСТ», «Интеллектуальная литература», «Книжный мир», «Молодая гвардия», «Университетская кни- 
га», «Художественная литература» и др.).

Председатель Попечительского совета Бунинской премии Игорь Михайлович Ильинский - ректор Московского гуманитарного университета, Президент Союза негосударственных вузов Москвы и Московской области, доктор философских наук, профессор, академик и член бюро Академии российской словесности, член Союза писателей России, лауреат Национальной премии в номинации «Художественная литература» за повесть «Живу и помню», лауреат Всероссийской историко-литературной премии «АлександрНевский», учрежденной Союзом писателей России, лауреат Золотой

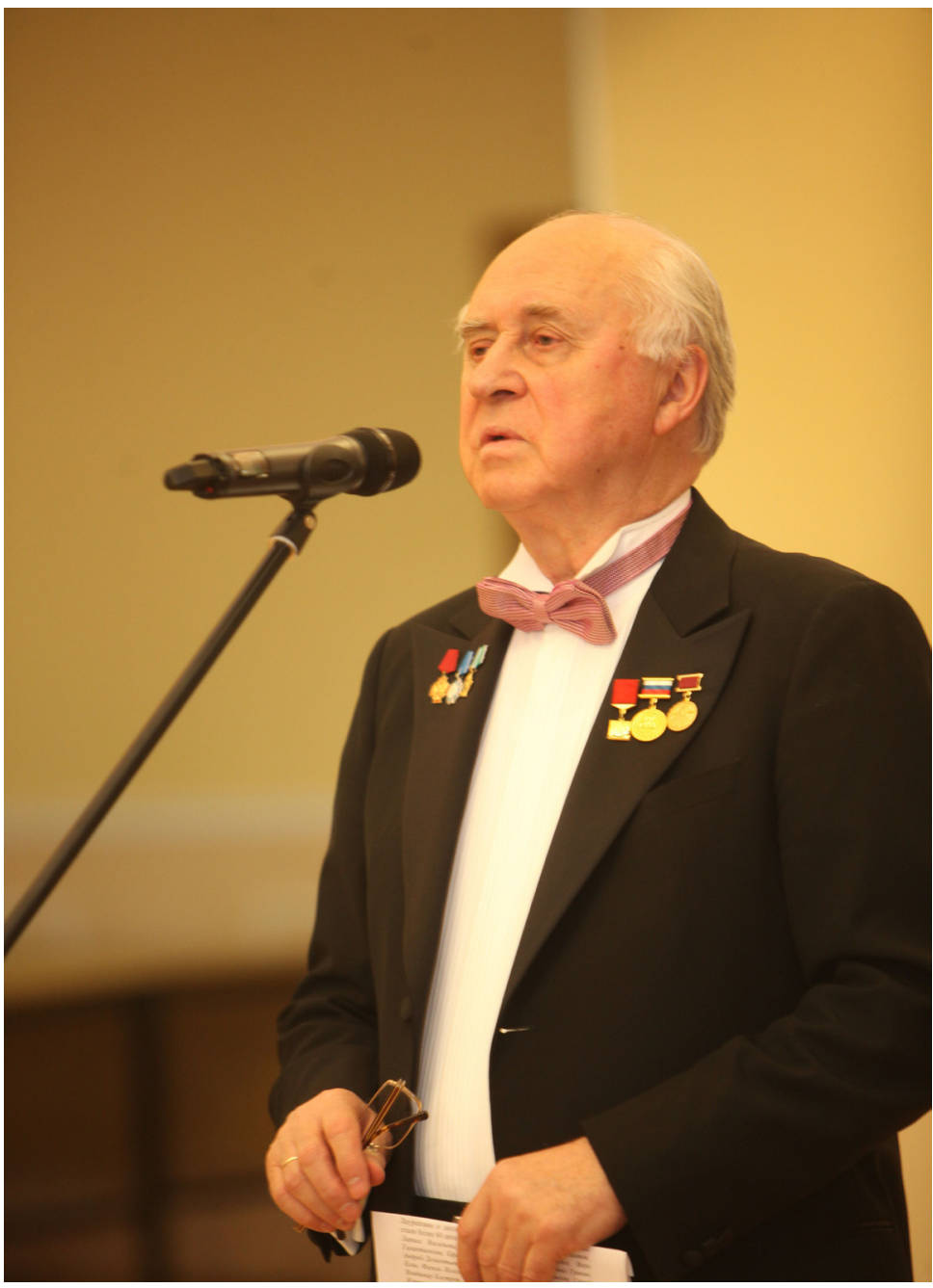
премии «Триумф просвещения» Академии Российской словесности и Общества ревнителей духовного единства народов «за выдающиеся гуманитарные достижения».

Жюри Бунинской премии возглавляет видный российский писатель и литературовед, член Президиума Союза писателей России, лауреат многих литературных премий Борис Николаевич Тарасов.

В состав Жюри Бунинской премии входят: Юрий Антонович Беляев писатель, общественный деятель. Президент Академии российской словесности, секретарь Правления Союза писателей России, Почетный академик Пушкинской академии; Юрий Леонидович Воротников, председатель Общества любителей российской словесности, член-корреспондент Российской академии наук, ученый секретарь Отделения литературы и языка Российской академии наук; Василий Петрович Гребенюк - доктор филологических наук специалист по русской литературе, секретарь Международного комитета славистов; Владимир Ильич Десятерик - писатель, журналист, директор издательства «Фонд имени Сытина», лауреат Премии Ленинского комсомола; Виталий Григорьевич Костомаров - выдающийся филолог, академик Российской академии образования, президент 
Государственного института русского языка имени Пушкина; Валерий Андреевич Луков - известный культуролог, Заслуженный деятель науки Российской Федерации, доктор философских наук, профессор, директор Института фундаментальных и прикладных исследований Московского гуманитарного университета; Юрий Дмитриевич Поройков - известный журналист и поэт, общественный деятель. Заслуженный работник культуры Российской Федерации. Многие годы возглавлял «Литературную газету и ИТАР-ТАСС; Владимир Викторович Портнов - известный поэт, публицист, главный редактор журнала «Студенчество: диалоги о воспитании» - единственного в России журнала по проблемам воспитательной работы в вузе, член Союза писателей России; Валерий Павлович Трыков - видный филолог, профессор кафедры всемирной литературы Московского педагогического государственного университета.

Председатель Попечительского совета Бунинской премии ректор университета, профессор Игорь Михайлович Ильинский и Председатель Жюри Бунинской премии Борис Николаевич Тарасов вручили премии новым лауреатам.

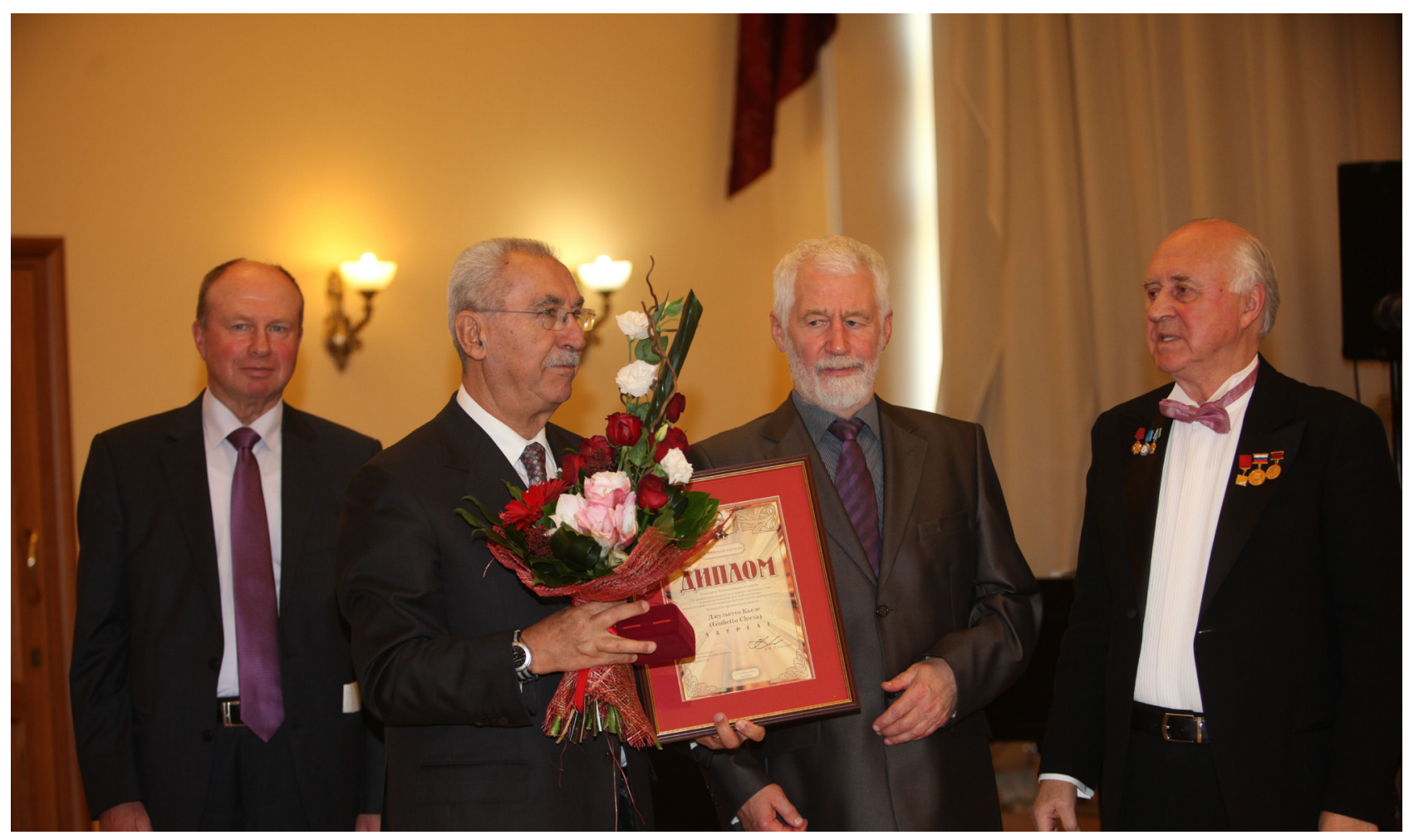

Решением Попечительского совета «За выдающиеся заслуги в защите свободы слова и возвеличивании русской культуры, многолетнюю плодотворную литературную деятельность» международная Бунинская премия присуждена всемирно известному итальянскому писателю, журналисту и общественному деятелю Джульетто Кьезе. 
Джульетто Кьеза своим творчеством внес выдающийся вклад в современную русскую публицистику. Его произведения переведены на португальский, немецкий, английский, японский и русский языки. Господин Кьеза - автор колонки в российском деловом еженедельнике «Компания» и в «Литературной газете». Его перу принадлежат многочисленные книги о Советском Союзе и России, которые сочетают исторический анализ, хронику и репортаж. В 2002 г. господин Кьеза стал лауреатом итальянской национальной премии «Культура за мир». Джульетто Кьеза -- яркий политический и общественный деятель, принципиальный публицист, который борется с несправедливостью, коррупцией, агрессией. Его признают и друзья, и недруги за стойкость убеждений, верность идеалам и несгибаемую волю.

Поздравления Джульетто Кьезе выразили писатель и публицист, член Союза писателей России Нина Васильевна Пушкова и российский журналист и прозаик, член Союза писателей Москвы, Союза писателей России, Союза журналистов России Дмитрий Альбертович Лиханов.

Премии Попечительского совета также присуждены Леониду Григорьевичу Ивашову и Владимиру Даниловичу Попову.

Леонид Григорьевич Ивашов - известный советский и российский военный и общественный деятель, генерал-полковник, одаренный писатель-публицист. Специалист в области геополитики, конфликтологии, военной истории и международных отношений. Доктор исторических наук, профессор кафедры международной журналистики МГИМО. Он возглавляет Академию геополитических проблем, преподаёт в Московском государственном институте международных отношений и Московском государственном лингвистическом университете, выступает на телевидении и в прессе с комментариями по вопросам внешней и внутренней политики. Постоянный автор газеты «Завтра». Пишет стихи. В этом году книгу Леонид Григорьевич выпустил книгу “Опрокинутый мир. Тайны прошлого - загадки грядущего”.

Владимир Данилович Попов - российский государственный деятель, публицист, заместитель главного редактора журнала «Наш современник». Он - автор четырёх книг и более 100 публикаций по экономическим, политическим и культурным проблемам России. Газета «Завтра» назвала его «профессиональным менеджером», «способным управлять крупными корпоративными активами», «государственником и поборником социального государства». В 2004 г. вышла его книга «Последние из великороссов? Мысли о „немыслимом“». В предисловии к изданию академик Дмитрий Львов отметил у автора «способность распознавать действительный смысл, масштаб явлений и предвидеть исходы». В своих выступлениях и публикациях Попов критически оценивает современные политические и экономические реформы в России 1990-х годов. Он - лауреат трёх лите- 
ратурных премий в публицистике, в том числе премии Вадима Кожинова.

Свои поздравления Владимиру Даниловичу отправил лауреат Бунинской премии Попечительского совета 2015 г. поэт и публицист Станислав Юрьевич Куняев.

Лауреатами Бунинской премии 2016 г. в номинации «художественная публицистика» стали: Андрей Ильич Фурсов (за книги «Вперед, к победе!», «Мировая борьба» и «Россия на пороге нового мира»); Юрий Юрьевич Болдырев (за книгу «Как нам избежать нищеты. Что делает и что должно делать правительство»); Иван Андреевич Есаулов (за книгу «Постсоветские мифологии»).

Известный русский историк и писатель Андрей Ильич Фурсов сочетает талант учёного и яркого публициста. Его публичные выступления на лекциях и научных конференциях хорошо известны в России и за рубежом. Он - автор более 400 публицистических статей по мировой истории и современности, член Русского интеллектуального клуба, академик Международной академии наук (Инсбрук, Австрия), директор Центра русских исследований Московского гуманитарного университета.

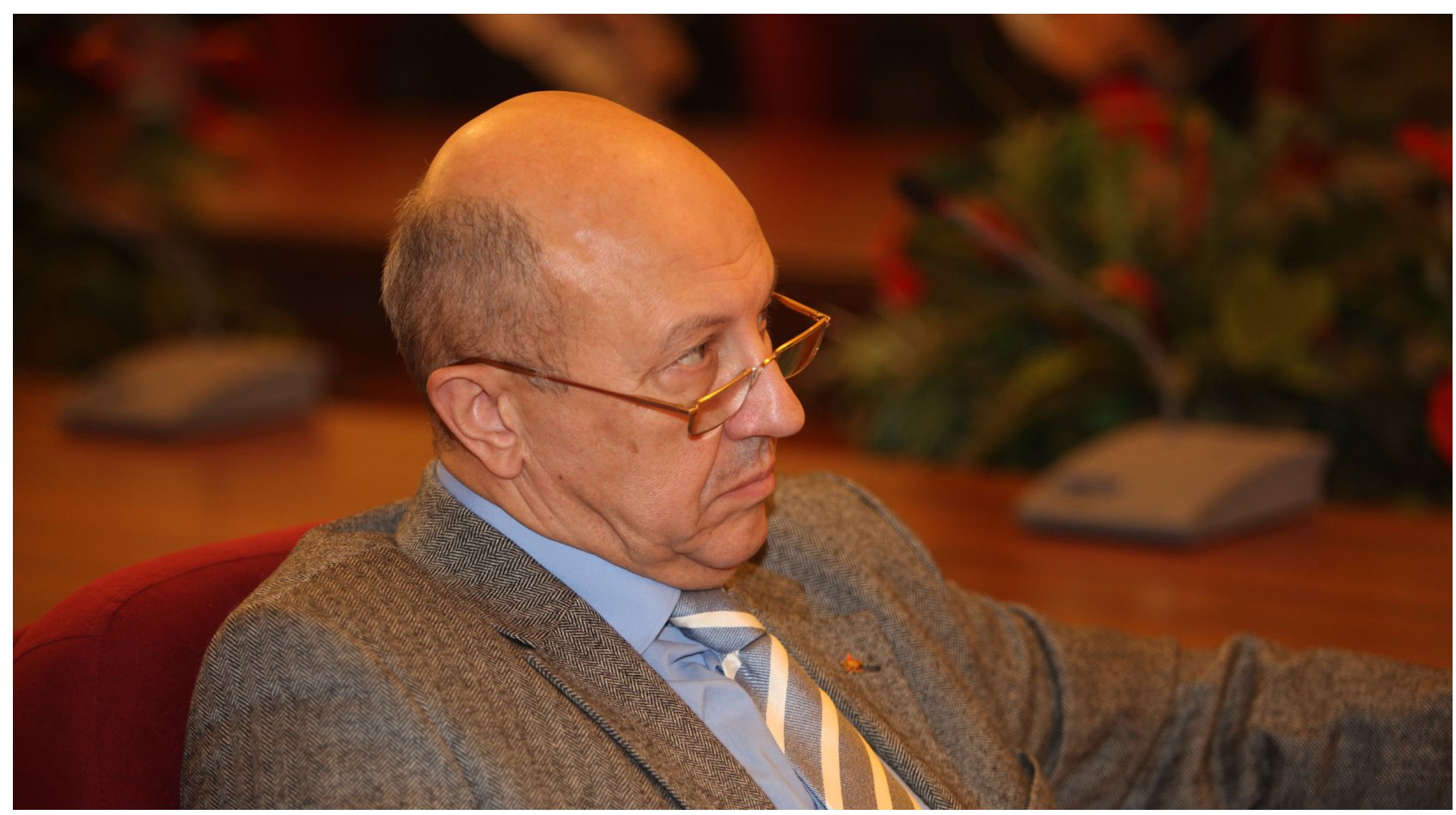

Фурсов - смелый и честный автор, истинный гражданин своей Родины, который не боится поднимать острые темы, дерзко вступая в информационные и идейные бои с хулителями нашей истории и культуры. Необходимо отметить стиль - лаконичный, наступательный, хлёсткий. В нем есть бунинское правдолюбие, сила и непримиримость ко лжи. Темперамент публициста сочетается с трезвым подходом аналитика, прекрасно 
знающего информационное и интеллектуальное поле Запада и умеющего использовать его в интересах России.

Бунинской премии в номинации «Художественная публицистика» за книгу «Как нам избежать нищеты. Что делает и что должно делать правительство» награждается Юрий Юрьевич Болдырев. Юрий Юрьевич Болдырев - известный публицист, писатель, государственный и общественный деятель, член редколлегии «Российского экономического журнала», колумнист «Литературной газеты» и «Свободной прессы», лауреат премии им. Антона Дельвига и премии газеты «Советская Россия». Он -автор восьми книг по политике и экономике современной России.

Книга Ю. Ю. Болдырева «Как нам избежать нищеты. Что делает и что должно делать правительство» - яркое явление в современной художественной публицистике, она написана прекрасным русским языком.

Бунинской премии в номинации «Художественная публицистика» за книгу «Постсоветские мифологии» награждается Иван Андреевич Есаулов. Иван Андреевич признан в отечественной и мировой гуманитаристике ведущим исследователем. Он опубликовал девять монографий, свыше 300 научных статей, изданных в разных странах мира и получивших широкое международное признание. Он - член Русской Академической Группы в США и Международного Общества Ф. М. Достоевского, его заслуги увенчаны Золотой Пушкинской медалью за вклад в развитие русской филологии.

Свои суждения Иван Андреевич утверждает в отчаянной и бесстрашной полемике с «Хозяевами Дискурса» современных СМИ, кто враждебен русской истории и народу, кто ведет повседневную работу по переформатированию массового сознания, кто внушает со страниц печатных и электронных изданий, что быть патриотом неприлично и стыдно. Он убеждает, что патриотами не становятся, а рождаются.

Для участия в конкурсе была прислана 71 заявка, представлены 118 книжных и журнальных публикаций оригинальных произведений. Заявки пришли из 21 российского города (Бийск, Волгоград, Вологда, Гурзуф, Екатеринбург, Ижевск, Иркутск, Кисловодск, Краснодар, Красноярск, Луга, Москва, Нижний Новгород, Новокузнецк, Пенза, Самара, Санкт-Петербург, Саранск, Северодвинск, Тула, Уфа). Конкурсные работы присланы из 7 зарубежных стран (Германия, Израиль, Казахстан, Канада, США, Украина и Финляндия).

Лауреатами и дипломантами Бунинской премии в разные годы стали более 60 литераторов: Владимир Алейников, Андрей Битов, Лариса Васильева, Мария Ватутина, Андрей Волос, Вера Галактионова, Ефим Гаммер, Глеб Горбовский, Даниил Гранин, Андрей Дементьев, Николай Добронравов, Борис Евсеев, Сергей Есин, Фазиль Искандер, Александр Кабаков, Александр Карасёв, Владимир Костров, Тимур Кибиров, Григорий Круж- 
ков, Вячеслав Куприянов, Марина Кудимова, Инна Лиснянская, Альберт Лиханов, Виктор Лихоносов, Владимир Личутин, Юрий Лощиц, Людмила Петрушевская, Юрий Поляков, Захар Прилепин, Александр Проханов, Евгений Фельдман и другие мастера художественного слова.

Спонсорами XI конкурса Бунинской премии выступили: Строительная компания «Гранстрой» (Генеральный директор Ющенко Петр Петрович), Московский индустриальный банк (Президент Арсамаков Абубакар Алазович), Национальный институт бизнеса (ректор Серей Иванович Плаксий), Институт современного искусства (ректор Сухолет Ирина Наумовна), Риэлтерская фирма «Вся недвижимость» (Генеральный директор Земнуров Рашид Султанович), Общество в ограниченной ответственностью «ГКК Ко» (Генеральныйдиректор Багдасарян ГеворкАнушаванович), Проектно-строительная фирма «НиКС», (Генеральный директор Клещевский Олег Николаевич), Закрытое акционерное общество «Русинтехноком» (Генеральный директор Солдаткин Александр Алексеевич), Общество с ограниченной ответственностью «Купола» (Генеральный директор Бензарь Оксана Александровна).

В актовом зале Московского гуманитарного университета собрались члены Попечительского Совета, члены Жюри и эксперты Бунинской премии, лауреаты премии прошлых лет, писатели и поэты, государственные и общественные деятели, руководители московских вузов, ученые, литературоведы и гуманитарии, издатели, журналисты, преподаватели и сотрудники, студенты и аспиранты Московского гуманитарного университета и других высших учебных заведений столицы.

Музыкальные подарки преподнесли лауреатам преподаватели, студенты и выпускники факультета культуры и искусства МосГУ Надежда Яныгина, лауреат международных конкурсов Василиса Белова, лауреаты Международного фестиваля «Стань звездой!» Валентина Низовкина и Татьяна Пушкарева. Лауреат международных конкурсов, выпускник кафедры культуры и искусства МосГУ Николай Рябуха исполнил любимый романс Леонида Григорьевича Ивашова «Целую ночь соловей нам насвистывал».

Имя И. А. Бунина священно для любителей русской литературы. Ему первому из русских писателей была присуждена Нобелевская премия по литературе 1933 г. «за художественное мастерство, благодаря которому он продолжил традиции русской классики в лирической прозе».

Бунинская премия была учреждена рядом российских негосударственных вузов в 2004 г. За прошедшие годы проведены конкурсы лучших произведений в прозе, поэзии, мемуаристике, публицистике, художественном переводе. 
Захаров Николай Владимирович - кандидат филологических наук, доктор философии (PhD), директор Центра теории и истории культуры Института фундаментальных и прикладных исследований Московского гуманитарного университета, ученый секретарь Шекспировской комиссии Российской академии наук. Адрес: 111395, Россия, г. Москва, ул. Юности, д. 5, корп. 6. Тел.: +7 (499) 374-75-95. Эл. адрес: nikoltine@yandex.ru

Zakharov Nikolay Vladimirovich, Candidate of Philology, PhD, Director, Center for Theory and History of Culture, Institute of Fundamental and Applied Studies, Moscow University for the Humanities; Academic Secretary, Shakespeare Committee, Russian Academy of Sciences. Postal address: Bldg. 6, 5 Yunosti St., 111395 Moscow, Russian Federation. Tel. +7 (499) 374-75-95. E-mail: nikoltine@yandex.ru 